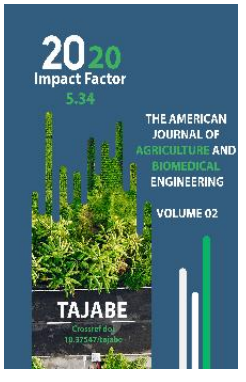

Journal Website: http://usajournalshub.c om/index,php/tajabe

Copyright: Original content from this work may be used under the terms of the creative commons attributes 4.0 licence.

\section{Biological Activity Of Oats Fruit Lipids (Avena Sativa L.)}

\author{
N.K. Yuldasheva \\ Institute Of Chemistry Of Plant Substances, The Academy Of Sciences Of Uzbekistan, \\ Tashkent, St. Mirzo-Ulugbek, 77. \\ S.D. Gusakova \\ Institute Of Chemistry Of Plant Substances, The Academy Of Sciences Of Uzbekistan, \\ Tashkent, St. Mirzo-Ulugbek, 77. \\ D.X.Nurullaeva \\ Tashkent Pharmaceutical Institute, Uzbekistan, Tashkent, St. Aybek, 45. \\ R.P. Zakirova \\ Institute Of Chemistry Of Plant Substances, The Academy Of Sciences Of Uzbekistan, \\ Tashkent, St. Mirzo-Ulugbek, 77.

\section{E.R. Kurbanova} \\ Institute Of Chemistry Of Plant Substances, The Academy Of Sciences Of Uzbekistan, \\ Tashkent, St. Mirzo-Ulugbek, 77. \\ N.T. Farmanova \\ Tashkent Pharmaceutical Institute, Uzbekistan, Tashkent, St. Aybek, 45.
}

\title{
ABSTRACT
}

Neutral lipids of oat fruits (Avena sativa L.) were studied varieties "Tashkent 1", harvested in the Samarkand region of the Republic of Uzbekistan. The study of the component composition of neutral oat lipids by TLC showed that they consist mainly of triacylglycerides and free FA, which were accompanied by hydrocarbons, phytosterols, triterpenoids, and Tocopherols. The study of the effect of heat and salt stress on the growth of wheat seedlings during pre-sowing treatment of wheat seeds with unsaponifiable substances of oat grain lipids showed that unsaponifiable substances of the studied object's lipids at a concentration of $0.0001 \%$ have a protective activity.

\section{KEYWORDS}

Neutral lipids; oat fruits; Alcohol-soluble sugars; Avena sativa; pectin; polysaccharides; starch. 


\section{ABBREVIATIONS}

WSPS water-soluble polysaccharides, PS - pectin substances, HMC - hemicellulose, TLC - Thin-layer chromatography, FA - Fatty Acids, NL - Neutral lipids,

\section{INTRODUCTION}

Lipids are widely distributed in nature and together with proteins and carbohydrates make up the bulk of organic substances of all living organisms, being an essential component of every cell [1].

The high content of lipids in the grain, which is in the maximum amount in the endosperm, refers oats to potentially oilseeds. In comparison with other cereals, preference is given to oats, since there are varieties with an oil content of up to $18 \%$ [2].

The study of the physiological and molecular mechanisms of plant resistance to the damaging effects of abiotic factors is one of the fundamental problems of biology[3].

The aim of the study is to study the biological activity of lipids of oat fruits.

\section{MATERIALS AND METHODS}

The objects of the study were the fruits (grains) of oats of the "Tashkent 1" variety, harvested in the Samarkand region of the Republic of Uzbekistan during the full maturation period in 2017-2018 (SeptemberOctober). After collection, the raw material was dried in air under a canopy at a temperature of $15-20^{\circ} \mathrm{C}$.

Isolation of lipids. Neutral lipids (NL) were isolated from crushed oat grain by gasoline extraction (t.kip. $72-80{ }^{\circ} \mathrm{C}$ ) on a magnetic stirrer at a temperature of $60^{\circ} \mathrm{C}$ for 2 hours in a triple repetition. The extracts were combined, the solvent was evaporated on a rotary evaporator, and the lipid yield was determined by weight.

The acid number of NL was determined, and the content of free fatty acids (FA) in them was calculated from this indicator, as described [4].

Non-saponified substances were isolated from NL by alkaline hydrolysis. Table 1 shows the results of the analyses. 
Table 1. Characteristics of neutral lipids of oat grain.

\begin{tabular}{|l|l|l|}
\hline $\begin{array}{l}\text { № } \\
\Pi \backslash \Pi\end{array}$ & Indicator & Content \\
\hline 1 & $\begin{array}{l}\text { Neutral lipid (oil content) when the actual } \\
\text { moisture content, \% by weight of grain }\end{array}$ & 3,72 \\
\hline 2 & Acid number NL, mg KOH/g & 14,11 \\
\hline 3 & Free fatty acids, \% by weight NL & 7,05 \\
\hline 4 & Non-saponified substances, \% by weight of NL & 5,1 \\
\hline
\end{tabular}

The composition of non-saponified substances was determined from TLC data on silica gel and Silufol plates. Hexane : ether 4:1; 3:2 and 7:3 solvent systems were used. Model substances (phytosterols, free FA) were used to identify the components. It was established that the main components of non-saponified substances were phytosterols, and hydrocarbons, triterpenols, and Tocopherols were identified as minor lipophilic substances. Next, the biological activity of NVPO was studied.

The influence of heat and salt stress on the growth of wheat seedlings during pre-sowing treatment of wheat seeds with non-saponified substances of oat fruit lipids (NVPO) was studied.

\section{METHOD}

During the tests, the method of Rakitin Yu. V. and Rudnik V. E. was used [5]. The seeds were soaked in $0.01, \quad 0.001$ and $0.0001 \%$ concentrations of $\mathrm{HBO}$ for 18 hours. The control was seeds soaked in water, and the "Uchkun" preparation in $0.0001 \%$ concentration was used as a reference [6].
In order to study the effect of salt stress on wheat seeds treated with NVPO, the latter were placed in 10 Petri dishes, $5 \mathrm{ml}$ of $1 \% \mathrm{NaCl}$ solution was added, and cultivated for 5 days in a thermostat at a temperature of $25^{\circ} \mathrm{C}$. To create heat stress, $5 \mathrm{ml}$ of tap water was poured into Petri dishes with processed seeds and kept in a thermostat with a temperature of $40^{\circ} \mathrm{C}$ for 8 hours a day for 5 days. Activity was assessed by linear growth of aboveground and underground organs of seedlings and by indicators of raw and dry weight of seedlings. Studies have shown that when exposed to high temperatures, seedlings obtained from treated seeds showed increased growth of the aboveground part of plants.

When exposed to 0.01 and $0.001 \%$ concentrations of NVPO, their length was 2.2 $\mathrm{cm}$ and $2.44 \mathrm{~cm}$ and exceeded the control version $(1.98 \mathrm{~cm})$ by 11.11 and $23.23 \%$, respectively.

These concentrations inhibited the growth of roots that were 3.08 and $3.70 \mathrm{~cm}$ long and were 21.23 and $5.35 \%$ below the control values, respectively. The maximum values were 
observed when seeds were treated with a $0.0001 \%$ dose of NVPO, the length of the stems $(2.47 \mathrm{~cm})$ was higher than the control by $24.75 \%$ and inferior to the reference version using the Uchkun biostimulator $(2.76 \mathrm{~cm})$ by $11.11 \%$. The same concentration stimulated the growth of roots, whose length was $4.47 \mathrm{~cm}$ against $3.91 \mathrm{~cm}$ of the control variant and was higher by $14.32 \%$. When processing seeds with a $0.0001 \%$ concentration of NWPO, the highest indicators were obtained for the weight of seedlings: the raw weight was $3.0 \mathrm{~g}$, the dry weight was $0.84 \mathrm{~g}$, which is 45.17 and $22.46 \%$ higher than the control, respectively. The same pattern was observed when exposed to salt stress. All three studied concentrations stimulated linear growth of the aboveground part of wheat seed seedlings to varying degrees. The maximum length of the stems was $3.93 \mathrm{~cm}$ when treated with a $0.0001 \%$ dose and exceeded the control variant (3.22 $\mathrm{cm}$ ) by $22.05 \%$. Concentrations of 0.01 and $0.001 \%$ inhibited root growth. The dose of $0.0001 \%$ showed stimulating activity: the length of the roots $(4.82 \mathrm{~cm})$ was higher than the control $(4.3 \mathrm{~cm})$ by $12.09 \%$, the aboveground part - by $12.09 \%$. When exposed to the same concentration, a high yield of raw root mass was observed. Their weight (1.5 g) was $12.7 \%$ higher than the control (1.33 g).

\section{CONCLUSION}

Thus, it was found that non-saponified substances (NVPO) of oat grain lipids in $0.0001 \%$ concentration have a protective activity when exposed to heat and salt stress.

\section{REFERENCES}

1. Nurullaeva, D. X. \& Farmanova, N. T. (2019). The lipid composition of the fruit of the oat. Materials of the scientific and practical conference "Medicine to Man. Modern problems of pharmacotherapy and prescription of medicines", p.p. 196197.

2. Jalal Abdu Kaid Xasan Almiklafi. (2014). Study of the protective effect of epibrassinolide on rapeseed plants under chloride salinity. The dissertation on competition of a scientific degree of candidate of biological Sciences, Moscow.

3. Banas, H. Debski, W. Banas, W.K. Heneen, A. Dahlqvist, M. Bafor, P.O. Gummeson, S. Marttila, A. Ekman, A.S. Carlsson, S. Stymne. (2007). Lipids in oat grain tissues (Avena sativa): differences in the content, deposition time, and composition of fatty acids. J. Exp. Bot., issue. 58, № 10, 24632470.

4. Sergeev, A. G. (Ed.). (1971). Guide to research methods, technochemical control and accounting of production in the fat and oil industry: Volume VI. Issue 1.

5. Rakitin, Yu. V. (Ed.). (1966). Methods for determining growth regulators and herbicides. The science. p.p. 182-197

6. X.M. Shaxidoyatov, N.K. Xidirova, N.M. Mamatkulova, G.V.Musaeva, U. Niyazmetov, A.A. Umarov, R.K. Karimov, M.M. Kiktev. "Method for obtaining a biostimulator”. Patent Uzb. № IAP 04589 11.2012. Certificate № 1a № 522. 06.04.2012 г. 